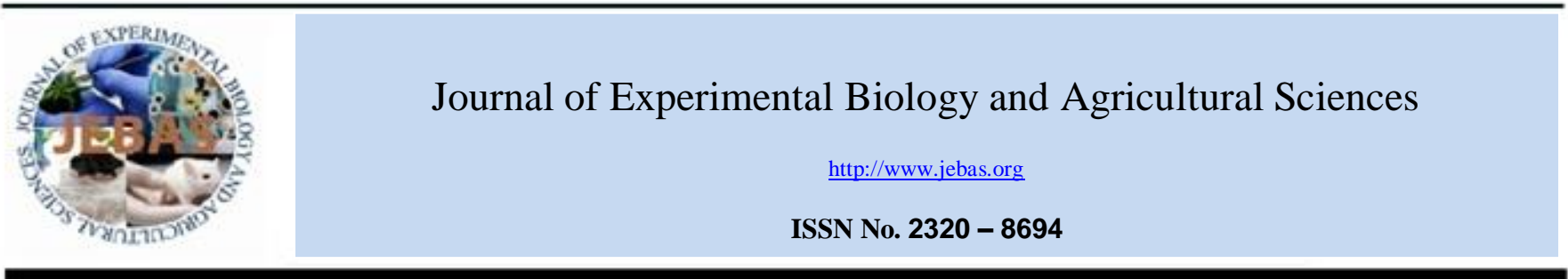

\title{
PRELIMINARY STUDY ON Eidolon helvum (Kerr, 1792) POPULATION DYNAMIC IN CÔTE D'IVOIRE, WEST AFRICA
}

\author{
Niamien Coffi jean Magloire ${ }^{1}$, Kadjo Blaise ${ }^{2}$, Dago Dougba Noël ${ }^{1 *}$, Koné Inza ${ }^{2}$, \\ N'Goran Kouakou Eliézer ${ }^{2}$
}

\footnotetext{
${ }^{1}$ Département de Biologie Animale, Unité de Formation et de Recherche (UFR) des Sciences Biologiques, Université Peleforo Gon Coulibaly, BP 1328 Korhogo, Côte d'Ivoire

${ }^{2}$ Laboratoire de Zoologie et Biologie Animale, Unité de Formation et de Recherche (UFR) des Biosciences, Université Félix Houphouët-Boigny, 22 BP 582 Abidjan, Côte d'Ivoire
}

Received - October 12, 2017; Revision - November 28, 2017; Accepted - December 19, 2017

Available Online - December 27, 2017

DOI: http://dx.doi.org/10.18006/2017.5(6).890.898

KEYWORDS
Straw-colored fruit bats
Dynamic of the population
Season effect
Main food resources
Côte d'Ivoire

* Corresponding author

E-mail: dgnoel7@gmail.com, noel.dago@upgc.edu.ci (Dago Dougba Noël)

Peer review under responsibility of Journal of Experimental Biology and Agricultural Sciences.

Production and Hosting by Horizon Publisher India [HPI] (http://www.horizonpublisherindia.in/).

All rights reserved.

\begin{abstract}
Relationship survey between diet and population size variation with regards to Eidolon helvum (Kerr, 1792), a near-threatened species has been achieved from August 2007 to July 2008 in the Commune of Plateau in Abidjan (Côte d'Ivoire; Western Africa). Indeed, perched bats count and excrement collection under daily dormitory have been performed with the purpose to evaluate E. helvum population size and dynamism (population variation) as well as to determine and/or discriminate the factors inducing that dynamism. E. helvum population in above mentioned experimental site, in relation to analyzed period (from August 2007 to July 2008) was estimated to $181384 \pm 15013.26$. Further, findings of present study suggested an increase in E. helvum population size from August to November, stabilization from November to February and reduction from March to July 2008. In addition, this study exhibited both food diversity $(\mathrm{r}=0.94 ; \mathrm{p}<0.0001)$ and abundance $(\mathrm{r}=0.90 ; \mathrm{p}<0.0001)$ as preponderant features influencing analyzed $E$. helvum population fluctuations. Food sources analysis revealed that $E$. helvum consumed Ficus exasperata Vahl (Moraceae) ( $\mathrm{r}=0.89 ; \mathrm{p}<0.0001)$, F. lutea Vahl $(\mathrm{r}=0.86 ; \mathrm{p}<0,001)$ and $F$. polita $(\mathrm{r}=0.61 ; \mathrm{p}<0.05)$ as main food resources. In conclusion findings of present study evoked that season and as well both food diversity and abundance are significant parameters (p-value $<0.05$ ) which influenced E. helvum bats specie population dynamism.
\end{abstract}

All the article published by Journal of Experimental Biology and Agricultural Sciences is licensed under a Creative Commons Attribution-NonCommercial 4.0 International License Based on a work at www.jebas.org.

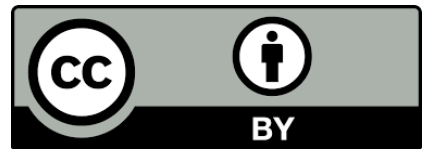




\section{Introduction}

Several parameters analysis such as population size and preferential habitat, diet and species threat can contribute to a permanent fauna management (Richter \& Cumming, 2006; Fleming and Racey, 2010). Chiropteran have huge systematical (Kunz \& Parsons, 2009; Herkt et al., 2016), ecological (Kunz et al., 2011; Meyer et al., 2016), pharmacological (Mildenstein et al., 2016), medical and veterinary (Moratelli \& Calisher, 2015; Saéz et al., 2015), economical (Kunz et al., 2011; Ghanem \&Voigt, 2012; Niamien et al., 2015; Williams-Guillen et al., 2016) and conservation values (Kingston, 2013; IUCN, 2015; Niamien et al., 2015; Mildenstein et al., 2016). Despite such multiple values, only few ecological data are available about them and this happened because of their nocturnal activities and the active flying way, making difficult their study (Kunz \& Parsons, 2009; Herkt et al., 2016).

In Côte d'Ivoire and particularly in Abidjan, the Commune of Plateau houses great population of straw-colored fruit bats Eidolon helvum (Kerr, 1792), as per IUCN (2015) report this species is near to threaten. Species E. helvum have significantly contribute in pollination of flower and in reconstitution of forest ecosystem (Kunz et al., 2011; Moratelli \& Calisher, 2015; Meyer et al., 2016; Williams-Guillen et al., 2016). In addition to this, these frugivorous also insure seed dispersion and favor seed germination of Iroko (Milicia excels Welw. Moraceae), which is a threatened forest gist in West Africa (Hawthorme, 1995; Tatlor et al., 2000). Despite these ecological value and/or importance of bats, these bats colonies have been less studied (Huggel-Wolf \& Huggel-Wolf, 1965; Thomas, 1983; Niamien et al., 2009; Niamien et al., 2010; Niamien et al., 2015; Niamien et al., 2017a; Niamien et al., 2017b). Thus, the Commune of Plateau, by virtue of the presence of the important community of fruit eater straw colored bats would be considered as a strategical site for the conservation of the biodiversity. In addition, central part of the Commune of Plateau is lined by different tree species, which are used as shelter by straw colored fruit bats (Thomas, 1983; Niamien et al., 2009; Niamien et al., 2010; Niamien et al., 2015). Population of this species disperses in the twiling to look for food and after eating, these fruit-eater bats return back to their accommodation site. They perched on the branches serving as roost (Figure 1). Also the gastric contain is continually excreted through the faeces and/or excrement during daily sleeping phase (Kunz \& Parson, 2009).

Studies about the factors which influence the dynamic of fruit eater straw colored bats populations and their migration are in scarcity. In fact, some approaches have been done in Mauritania and in Kenya (Cosson et al., 1996; Richter \& Cumming, 2006), but these information's are not enough to explain population distribution and population dynamic of E. helvum. In Côte d'Ivoire, only Thomas (1983) has carried out studies about the migration of fruit-eater straw-colored bats. However, this author has not given any information about the causes of the variation among the population size and pattern of migration.

The general hypothesis is that the variations of abundance are according to availability of the food. The present study carried out from August 2007 to July 2008, is a contribution to a better knowledge of the ecology of fruit-eater straw-colored bats in order to insure a rational and lasting management. It aims specifically at determining the numbers of straw-colored fruit bats, their dynamic and to evaluate the influence of the availability of the food on the abundance fluctuations.

\section{Materials and Methods}

\subsection{Study site}

The Commune of Plateau stretches out between longitudes $4^{\circ} 10^{\prime}$ and $4^{\circ} 50^{\prime}$ 'West and latitudes $5^{\circ} 10^{\prime}$ and $5^{\circ} 80^{\prime}$ North, on a surface area of $2.5 \mathrm{~km}^{2}$. It is located in the center of Abidjan (South of Côte d'Ivoire).

Abidjan has humid equatorial climate regime, characterized by four seasons as following: small dry season from August to September, small rainy season from October to November, a long dry season (from December to March) and a long rainy season from April to July) (Brou, 1997).

\subsection{Data collection}

\subsubsection{Population size}

The population size of the straw-colored fruit bats in the Commune of Plateau was determined by counting the perched and sleeping bats (Kunz, 2003; O'Shea et al., 2003; Krebs, 2006; Hayes et al., 2009; Hayman et al., 2012). Visits were done on Saturdays during day light from $7 \mathrm{Am}$ to $5 \mathrm{Pm}$ to take into account the poaching activities (Niamien et al., 2015). Counting has been performed on Saturdays, except from football match days in Felix Houphouët-Boigny stadium adjoining the study zone. In fact, the spectators cry during football matches bring out a massive flight of bats (Mann et al., 2002; Hayes et al., 2009; Nordt \& Klenke, 2013). That counting was done in 16 roosting sites (Figure 1), before the waking up and the massive agitation of bats, by counting the perched bats on branches of each tree, from its base towards the extremity whatever the age and the sex, usually counting carried out manually but some time help of the binoculars was also taken (Kunz, 2003; O'Shea et al., 2003; Krebs, 2006; Hayes et al., 2009; Hayman et al., 2012; Niamien et al., 2017 b). 


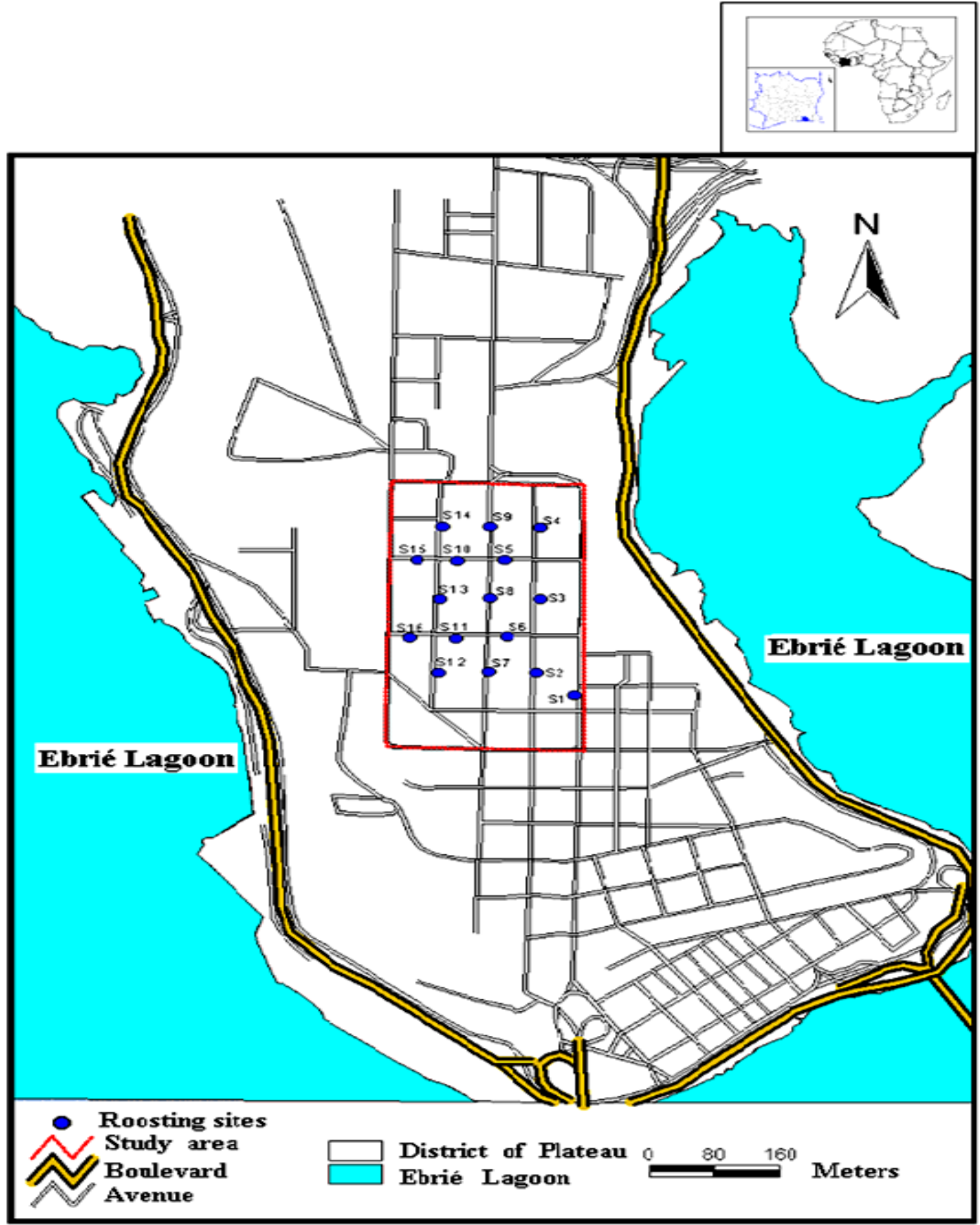

Figure 1 Cartography of 16 roosting sites of straw-colored fruit bats in the Commune of Plateau in Abidjan from August 2007 to July 2008.

Journal of Experimental Biology and Agriculture Science http://www.jebas.org 


\subsubsection{Diet composition}

\subsubsection{Faeces collection}

The diet of the straw-colored fruit bats in Plateau Commune was studied by analyzing their faeces and/or excrement composition (Thomas, 1988; Niamien et al., 2009, Niamien et al., 2017a). The excrement was collected from August 2007 to July 2008 under the daily roosting sites (Figure 1). Excrement was collected with the help of spatula and referenced pill machines (site and month). Collection preferentially were executed on Sundays with the purpose to take into account sweeping activities of the pavement of the Commune of Plateau, which is going on the working days, which likely eliminate bat excreted faeces and/or excrement (Niamien et al., 2009; Niamien et al., 2017a).

\subsubsection{Sort out and identification of taxons}

In the laboratory, the content of each pill machine is spilled on a sieve of $1 \mathrm{~mm}$ of mesh. Excrement washed with water in order to isolate the seeds. These isolated seeds were identified with the help of keys suggested by Hutchinson \& Dalziel (1963) and AkéAssi $(2001,2002)$ and then the collection of reference of National Floristic Center of the University Félix Houphouet-Boigny (Côte d'Ivoire). The vegetable species of faeces only constituted of pulp were determined on the basis of their color, texture and smell (Thomas, 1982; Thomas, 1984; Thomas, 1988; Niamien et al., 2009; Niamien et al., 2017a). Indeed, the taxon were identified and counted.

\subsubsection{Expression of diet results}

\subsubsection{Abundance relative of food}

The abundance of food in the nature and particularly in the nutrition zone is explained by the great frequency of items in the feaces. On this basis, the index of the food abundance was estimated by counting the items species found in the feaces of the straw-colored fruit bats (Thomas, 1982; Thomas, 1988).

\subsubsection{Diversity index of Shannon-Weaver $\left(\mathrm{H}^{\prime}\right)$}

The calculated diversity index of Shannon ( $\left.\mathrm{H}^{\prime}\right)$ on the basis of abundance relative to each vegetable species present in the strawcolored fruit bats excrement (Ramade, 2012), permitted to determine the specific diversity of the exploited food resources by straw-colored fruit bats. It varies from 1 to 5 ; as following:

$$
\mathrm{H}^{\prime}=-\sum(\mathrm{ni} / \mathrm{N}) \ln (\mathrm{ni} / \mathrm{N})
$$

Where as

$$
\ln =\text { Natural logarithm, }
$$

$n i=$ number of faeces and/or excrement in an item $\mathrm{i}$,

$\mathrm{N}=$ Total examined feaces and/or excrement number. The present Shannon index (diversity index) was calculated with GWBASIC software.

\subsection{Statistical analysis}

Before any analysis, the distribution of normal data was checked by using the Shapiro-Wilk test. The average numbers of strawcolored fruit bats were compared to variances analysis. Correlation between straw-colored fruit bats numbers and (i) the diversity of consumed resources, (ii) the abundance of food and (iii) the main food resources respectively were realized via a Spearman correlation test. Finally, the Linear Generalized Model has permitted to test the diversity effects of the consumed items and the abundance of food on the distribution of straw-colored fruit bats. The present analysis was performed by using STATISTICA software (version 7.1).

\section{Results}

\subsection{Numbers and temporal variations}

The present survey based on 48 observations, performed in Plateau Commune from August 2007 to July 2008, recorded a straw-colored fruit bats number ranging between 11687 (minimum value relative to July) and 308409 (maximum value relative to November) (Table 1). Monthly average of bat population in the present processed experimental site has been estimated to $181384 \pm 15013.26$ (Table 1). Further, February and November months have been recorded as exhibiting the highest number of bats ratio as opposed to March, April, May, June and July month (p-value <0.05) (Table 1).

In addition, the present analysis showed a significant increase of processed straw-colored fruit bats population size from August to November $(\mathrm{ddl}=3 ; \mathrm{F}=31.15 ; \mathrm{p}<0.001)$. The same survey evidenced the stabilization of that population from November to February $(\mathrm{ddl}=3 ; \mathrm{F}=2.1 ; \mathrm{p}>0.05)$ and its noticeable progressive falling down from March to July (ddl = 4; F = 15; p < 0.001) (Table 1). Comparative statistical and/or clustering analysis evidenced a significant difference ( $\mathrm{p}$-value <0.05) between both dry and raining seasons in assessing bats population dynamism (Table 1).

\subsection{Food availability}

Findings of study revealed eleven fruits tree species viz., Carica papaya L. (Caricaceae), Elaeis guineensis Jacq. (Arecaceae), Ficus benjamina L. (Moraceae), Ficus exasperata Vahl (Moraceae), Ficus lutea Vahl (Moraceae), Ficus polita Vahl (Moraceae), Ficus sp. (Moraceae), Ficus sur Forssk. (Moraceae), 
Table 1 Descriptive statistic survey of straw-colored fruit bats population size variation from August 2007 to July 2008 in Plateau Commune.

\begin{tabular}{|ccccccccc|}
\hline & \multicolumn{9}{c}{ Statistical parameters } \\
Months & Minimum & Mean & Maximum & Median & $1 / 4$ Quartil & 3/4 Quartil & Variance & p-value \\
\hline August & 202804 & $205850.13 \pm 1801^{\mathrm{d}}$ & 210929 & 204833.5 & 203343 & 208357 & 12983869 & 0.5 \\
\hline September & 204679 & $210200 \pm 2396^{\mathrm{d}}$ & 215721 & 210200 & 206442 & 213958 & 22974311 & 0.57 \\
\hline October & 196898 & $199656 \pm 1291^{\mathrm{e}}$ & 202254 & 199736 & 197477 & 201835 & 6671256 & 0.96 \\
\hline November & 304015 & $306646 \pm 959^{\mathrm{a}}$ & 308409 & 307080 & 305263 & 308029 & 3684855 & 0.16 \\
\hline December & 283936 & $288720 \pm 2574^{\mathrm{b}}$ & 296016 & 287464 & 285528 & 291912 & 26503339 & 0.36 \\
\hline January & 273153 & $280446 \pm 3087^{\mathrm{c}}$ & 287738 & 280446.5 & 275799 & 285093 & 38124373 & 0.13 \\
\hline February & 304406 & $304700 \pm 187^{\mathrm{a}}$ & 305231 & 304581.5 & 304435 & 304965 & 141364.7 & 0.18 \\
\hline March & 172718 & $174536 \pm 1173^{\mathrm{f}}$ & 177890 & 173768 & 172928.5 & 176143.5 & 5508457 & 0.2 \\
\hline April & 100885 & $102637.5 \pm 736^{\mathrm{g}}$ & 104392 & 102636.5 & 101546.5 & 103728.5 & 2172251 & 0.14 \\
\hline May & 68424 & $70456 \pm 843^{\mathrm{h}}$ & 72478 & 70461 & 69240 & 71671.5 & 2847997 & 0.44 \\
\hline June & 19422 & $20422 \pm 550^{\mathrm{i}}$ & 21952 & 20157 & 19649 & 21195 & 1213021 & 0.48 \\
\hline July & 11687 & $12340 \pm 303^{\mathrm{j}}$ & 13015 & 12329 & 11841.5 & 12838.5 & 368018 & 0.051 \\
\hline
\end{tabular}

$\mathrm{ddl}=11 ; \mathrm{F}=44.99 ; \mathrm{p}=0.0017 ;$ a month with high number of bats, b: month with moderate number of bats; c, d, e, f, g, h, i: months with weak number of bats.

Ficus umbellata Vahl (Moraceae), Mangifera indica L. (Anacardiaceae) and Psidium guajava L. (Myrtaceae) as a part of straw-colored fruit bats diet. Among these, fruits of F. exasperata, $C$. papaya, F. polita and M. indica are the most exploited one. In addition, excluding $M$. indica, the majority of the eaten fruits by the straw-colored fruit bats were more abundant during the long dry season (Figure 2).

Also, obtained and/or computed Shannon variability index ( $\left.\mathrm{H}^{\prime}\right)$ highlighted the diversity of food resources and advised nutriment increase from August (1.8) (small dry season) to February (2.3) (long dry season), which exhibited the peak and/or maximum value of processed Shannon index. However, this index (H') decreased from March (2.01) (long dry season) to June (long rainy season) which corresponded to the minimum reaching Shannon index value (1.5). Finally, the diversity of exploited items has increased in July (1.6), matching to the end of the long rainy season (Figure 3).

\subsection{Correlations between the number of straw-colored fruit bats and the availability of food}

Relationship analysis between straw-colored fruit bats numbers and diversity of items was also assessed during the study. The Spearman correlation test showed a strong correlation between bats numbers and the diversity of the eaten items $(\mathrm{N}=12 ; \mathrm{r}=0.94$; $\mathrm{p}<0.0001)$. In fact, the Generalized Linear Model revealed that
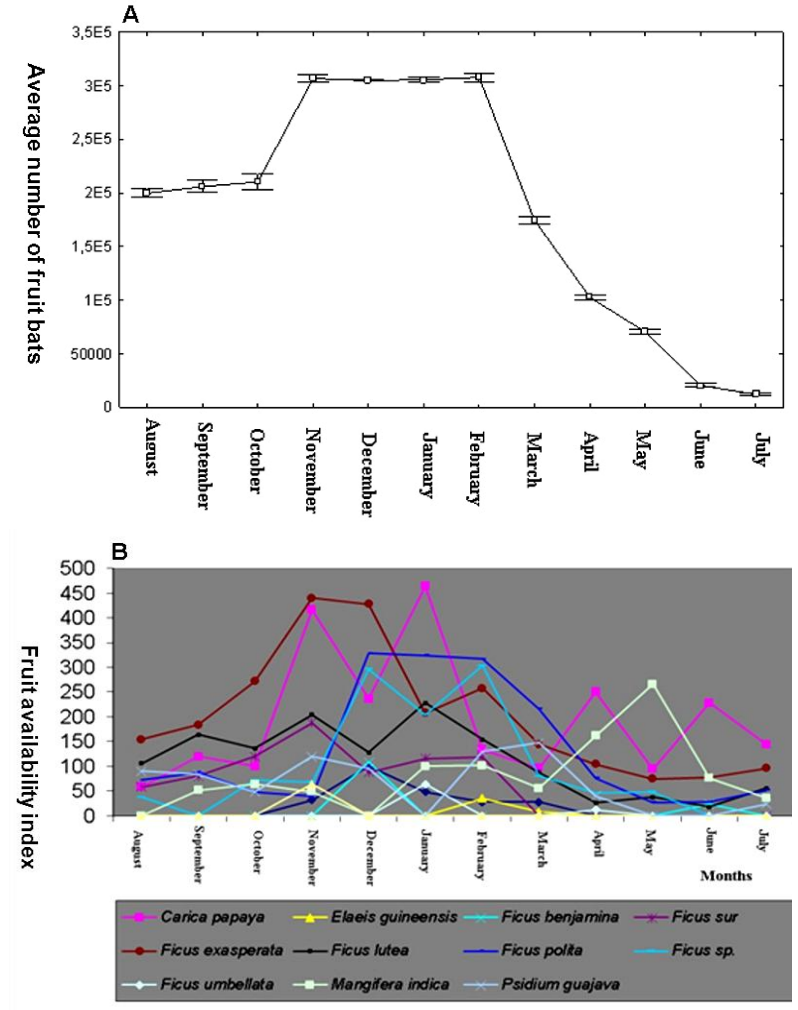

Figure 2 Variations of the straw-colored fruit bats population size (A) according to the food availability (B) of the Commune of Plateau in Abidjan from August 2007 to July 2008.

Journal of Experimental Biology and Agriculture Science http://www.jebas.org 


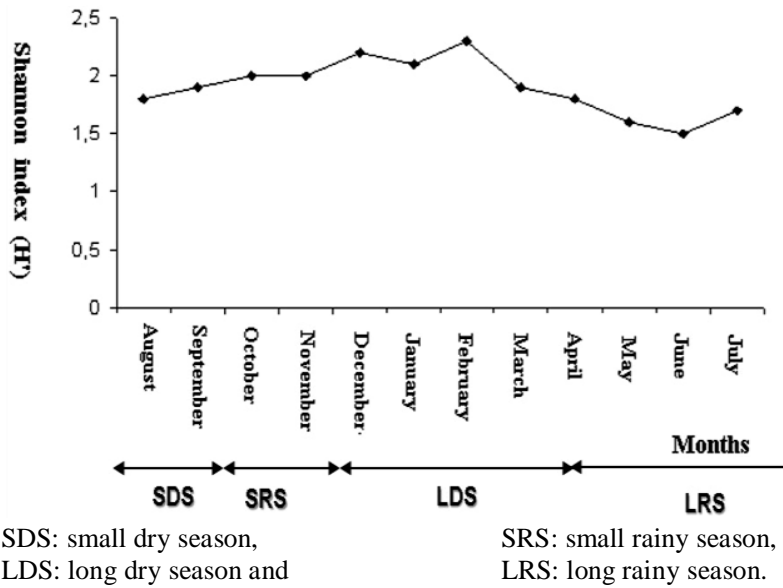

Figure 3: Monthly variations of food diversity exploited by the fruit bats Eidolon helvum in the Commune of Plateau in Abidjan from August 2007 to July 2008.

the distribution of straw-colored fruit bats in our experimental site was according to the diversity of exploited food resources (GLM: $\mathrm{ddl}=11 ; \mathrm{W}=68,89 ; \mathrm{p}<0.001)$.

Further, relation survey between straw-colored bats numbers and food abundance was also carried out in present study. Result of this study suggested a strong agreement (high correlation) between straw-colored fruit bats number and food abundance $(\mathrm{N}=12 ; \mathrm{r}=0.90 ; \mathrm{p}<0.0001)$. Indeed, the performed Generalized Linear Model survey certified that observation by highlighting the distribution of straw-colored fruit bats in the Commune of Plateau as influencing the abundance of exploitable food resources (GLM: $\mathrm{ddl}=11 ; \mathrm{W}=86.12 ; \mathrm{p}<0.001)$.

As regards straw-colored fruit bats main food resources, findings of study suggested four fruits species trees i.e. C. papaya, $F$. exasperata, F. lutea and $F$. polita (Figure 2), as regularly and most exploited. In addition, in except of $C$. papaya $(\mathrm{r}=0.31 ; \mathrm{p}>$ 0.05), the correlation test of rank of Spearman revealed that the numbers of $E$. helvum are significantly linked to $F$. exasperata $(\mathrm{r}=0.89 ; \mathrm{p}<0.0001)$, of $F$. lutea $(\mathrm{r}=0.86 ; \mathrm{p}<0.001)$ and of $F$. polita $(\mathrm{r}=0.61 ; \mathrm{p}<0.05)$ fruits availabilities. Consequently, $F$. exasperata, $F$. lutea and $F$. polita are the main fruit species, responsible of the variation of the straw-colored fruit bats on one hand and on the other hand, determine the migration of strawcolored fruit bats, a near-threatened species in our experimental site (Commune of Plateau; Abidjan Côte d'Ivoire).

\section{Discussion and conclusions}

Food seems to be the main cause conditioning straw-colored fruit bats population dynamism. Then, size increasing as regards strawcolored fruit bats population from August to November seems to be linked to the diversity and the abundance of food resource
(Cosson et al., 1996; Richter \& Cumming, 2006; Durant et al., 2013; Cisneros et al., 2015). Afterwards, food limitation would ensure the upholding of straw-colored fruit bats numbers from November to February (Figure 2). Then, this food proportion may normalize analyzed straw-colored fruit bats population size guaranteeing and ensuring their daily needed energy (Cumming \& Bernard, 1997; Fleming \& Eby, 2003; Richter \& Cumming, 2006; Klingbeil \& Willing, 2010). Finally, observed reduction as regards straw-colored bats population size for March seems to be dictated and/or associated to the fall of food resource availability (Figures 2). From this on, the individual producers would migrate from March to July, to profit from peaks of food abundance in order to satisfy their high need in energy (Fleming \& Eby, 2003; Richter \& Cumming, 2006; Durant et al., 2013; Kingston, 2013; Cisneros et al., 2015).

The population size variation reveals that the largest numbers of straw-colored fruit bats are observed in the long dry season (Table 1). That same observation was done on the colony of straw-colored fruit bats of Accra, Ghana (Hayman et al., 2012). That could be explained by the fact that the diversity and abundance peaks of food occur in this season, reducing the latter (food) competition. That manna charm the straw-colored fruit bats, since that fruits are produced to attract the frugivorous (Gautier-Hion, 1990; Richter \& Cumming, 2006; Fahr \& Kalko, 2011; Hagen \& Saho, 2011; Cisneros et al., 2015).

Result of study evidenced $F$. exasperata, F. lutea and F. polita as the most exploited food resources (Figure 2) linking them to the consistent variations observed in the present analyzed bats population. In the National park of Kasanka (Zambia), four fruit species are the most eaten by the colony of straw-colored fruit bats. There are Syzygium guineense guineense (Wild.) Dc. (Myrtaceae), S. guineense huillense (Hiern) F. White (Myrtaceae), Upaca banguelensis Müll. Argr. (Euphorbiaceae) and U. kirkiana Müll. Argr. (Euphorbiaceae), which are resulted the main food resources responsible of abundance fluctuations (Richter, 2004; Richter \& Cumming, 2006).

In scope of that study, the relative availability of food (diversity and abundance) was calculated on the basis of the collected faeces and/or excrement under the daily dormitory sites of straw-colored fruit bats of the Commune of Plateau. That choice is linked to the fact that the feeding zone of that frugivorous is up to now not determined. These facts could constitute an obstacle to the suitable evolution of food availability. However, that deficiency can be skirted. In fact, results about food availability obtained from excrement collected under the dormitory are representative of food variation obtained in natural area (Thomas, 1982; Thomas, 1988). For a more complete evaluation of food resources availability, the determination of the feeding sites of the strawcolored fruit bats of the Commune of Plateau in Abidjan is 
indispensable. Therefore, the linear transect methods and scores methods as used by Chapman et al. (1994) and Richter \& Cumming (2006) would be to test.

Considering as a whole, the present analyzed straw-colored fruit bats population in the Commune of Plateau increased from August to November, was stable up to February before falling down from March to July. The greatest numbers as regards that population size were observed during the long dry season and the weakest during long rainy season. The straw-colored fruit bats population number claimed to be in agreement with food resource diversity and abundance. Also, our findings exhibited $F$. exasperata, $F$. lutea and $F$. polita fruit trees as responsible of bats population dynamism and/or variation as well as migration activities. Therefore, the present study suggested straw-colored fruit bats population size and diversity and as well reproduction needed and food resource availability as selective factors influencing the latter's population fluctuation and migration. To ensure the upholding of the integrality of this population of this species (a near-threatened species), the protection of their key food resources is indispensable. It goes through determining and protecting of nutrition zones. In addition, the services in charge of protecting the fauna could proceed to growing these main fruit resources in order to reduce the impacts of straw-colored fruit bats population and its immigrants on the surrounding plantations of industrial fruit trees avoiding conflicts able to increase their vulnerability.

\section{Acknowledgements}

We thank the National Floristic Center of the University Félix Houphouët-Boigny of Abidjan and particularly the Emeritus professor Aké-Assi Laurent $(\dagger)$ for the identification of eaten items by the straw-colored fruit bats. We also thank The Direction of Nature Protection, the Technical Service of the Municipality of Plateau and the Judicial Police who give us the permission to do this research. Finally, we would like to express our gratitude to the professor Donaldson Thomas $(\dagger)$ of the University of Sherbrook (Canada), to the Bat Conservation International (BCI) and African Bat Conservation (ABC), which offered us the bibliography.

\section{Conflict of Interest}

Authors would hereby like to declare that there is no conflict of interests that could possibly arise.

\section{References}

Aké-Assi L (2001) Flore de la Côte d'Ivoire, tome 1: Catalogue systématique, biogéographique et écologique. Boissiera, Génève.
Aké-Assi L (2002) Flore de la Côte d'Ivoire, tome 2: Catalogue systématique, biogéographique et écologique. Boissiera, Génève.

Brou Y(1997) Analyse et dynamique de la pluviométrie en milieu forestier Ivoirien. Thèse de troisième cycle de l'Université d'Abidjan, Cocody.

Chapman CA, Wrangham R, Chapman, LJ (1994) Indices of habitat wide fruit abundance in tropical forest. Biotropica 26: 160171.

Cisneros LM, Fagan ME, Willig MR (2015) Effects of humanmodified landscapes on taxonomic, functional, and phylogenetic dimensions of bat biodiversity. Diversity and Distributions 21:523-533.

Cosson JF, Tranier M, Colas F (1996) On the occurrence and possible migratory behaviour of the fruit bat Eidolon helvum in Mauritania, Africa. Journal of African Zoology 10: 369-371.

Cuming GS, Bernard RTF (1997) Rainfall, food abundance and timing of parturition In African bats. Oecologia 111: 309-317.

Durant KA, Hall RW, Cisneros LM, Hyland RM, Willig MR (2013) Reproductive Phenologies of phyllostomid bats in Costa Rica. Journal of Mammalogy 94:1438-1448.

Fahr J, Kalko EKV (2011) Biome transitions as centres of diversity: habitat heterogeneity and diversity of West African bat assemblage across spatial scales. Ecography 34: 177-195.

Fleming TH, Eby P (2003) Ecology of bat migration. In: Kunz TH, Fenton MB (Ed). Bat Ecology, The University of Chicago press, Chicago, USA.

Fleming TH, Racey PA (2010) Island bats: Evolution, ecology and conservation. University of Chicago Press, Chicago.

Gautier-Hion A (1990) Coadaptations entre rythmes de fructification et frugivorie en forêt tropicale du Gabon : Mythe ou réalités. Revue d'Ecologie (Terre et vie) 40: 405-434.

Ghanem SH, Voigt CC (2012) Increasing awareness of ecosystem services provided by bats. Advances in the Study of Behavior 44:279-302.

Hagen EM, Sabo JL (2011) A landscape perspective on bat foraging ecology a long rivers: Does channel confinement and insect availability influence the response of bats to aquatic resources in riverine landscapes? Oecologia 166: 751-760.

Hawthorme WD (1995) Ecological profiles of Ghanian forest trees. Oxford forestry institute, Oxford. 
Hayes JP, Ober HK, Sherwin RE (2009) Survey and monitoring of bats. In: Kunz TH, Parsons S (Ed.), Ecological and behavioral methods for the study of bats, Johns Hopkins University Press, Maryland, USA.

Hayman DTS, McCrea R, Restif O, Suu-ire R, Fooks AR, Wood JLN, Cunningham AA, Rowcliffe JM (2012) Demography of straw-colored fruit bats in Ghana. Journal of Mammalogy 93:1393-1404.

Herkt KMB, Barnikel G, Skidmore AK, Fahr J (2016) A highresolution model of bat diversity and endemism for continental Africa. Ecological Modelling 320: 9-28.

Huggel-Wolf HJ, Huggel-Wolf M (1965) La biologie de Eidolon helvum (Kerr) (Megachiroptera). Acta Tropica 22:1-10.

Hutchinson J, Dalziel JM (1963) Flora of West Tropical Africa, $2^{\text {nd }}$ Edition. Crown Agents for oversea governments and Administration, London.

IUCN (2015) The IUCN Red List of Threatened Species. hptt://www.iucnredlist.org/downloaded on 9 September 2015.

Kingston T (2013) Response of bat diversity to forest disturbance in Southeast Asia: insights from long-term research in Malaysia. In: Adams RA, Pedersen SC (Ed). Bat evolution, Ecology and Conservation, Springer, New York, USA.

Klingbeil BT, Willig MR (2010) Seasonal differences in population ensemble and community level responses of bats to landscape structure in Amazonia. Oikos 119:1654-1664.

Krebs CJ (2006) Mammals. In: Sutherland W (Ed). Ecological census Techniques, Cambridge University Press, New York, USA.

Kunz TH (2003) Censusing bats: challenge, solutions and sampling biases. In: O'Shea TJ, Bogan MA (Ed.), Monitoring trends in bat populations of the United States and territories: Problems and prospects US, Geological survey, biological resources Division, information and technology report, USGS/BRD/ITR-2003-003.

Kunz TH, Parsons S (2009) Ecological behavioural Methods for the study of bats $2^{\text {nd }}$ Edition. The Johns Hopkins University press, New York.

Kunz TH, Braun de Torrez E, Bauer D, Lobova T, Fleming TH (2011) Ecosystem services provided by bats. Annals of the New York Academy of Sciences 1223:1-38.
Mann SL, Steihl RJ, Dalton VM (2002) Effects of cave tours on breeding Myotis velifer. Journal of Wildlife Management 66: 618624.

Meyer CFJ, Aguiar LMS, Aguirre LF, Baumgarten J, Clarke FM, Cosson JF, Villegas SE, Fahr J, Faria D, Furey N, Henry ML, Jenkins RKB, Mildenstein T, Tanshi I, Racey PA (2016) Exploitation of Bats for Bushmeat and Medicine. In: Voigt CC, Kingston T (Eds.), Bats in the Anthropocene: conservation of bats in a changing world, Springer International, Berlin, Germany.

Mildenstein T, Tanshi I, Racey PA (2016) Exploitation of Bats for Bushmeat and Medicine. In: Voigt CC, Kingston T (Eds.), Bats in the Anthropocene: Conservation of bats in a changing world, Springer International, Berlin, Germany.

Moratelli R, Calisher HC (2015) Bats and zoonotic viruses: Can we confidently link bats with emerging deadly viruses? Memórias do Instituto Oswaldo Cruz, Rio de Janeiro 110:1-22.

Niamien CJM, Yaokokoré-Béibro KH, Koné I, Yao SS, N'Goran KE (2009) Données préliminaires sur les habitudes alimentaires des chauves-souris paillées, Eidolon helvum (Kerr, 1792) (Chiroptera: Pteropodidae) de la commune d'Abidjan-Plateau (Côte d'Ivoire). Agronomie Africaine 21:231-240.

Niamien CJM, Yaokokoré-Béibro KH, Koné I, N'Goran KE (2010) Données préliminaires sur l'écologie des chauves-souris frugivores de la commune du Plateau (Abidjan, Côte d'Ivoire). Sciences et Nature 7:21-30.

Niamien CJM, Kadjo B, Dago DN, Koné I, N'Goran KE (2015) Initial data on poaching of Eidolon helvum (Kerr, 1792) nearthreatened species in Côte D'Ivoire, West Africa. European Journal of Scientific Research 135:219-227.

Niamien CJM, Kadjo B, Koné KCH, N'Goran KE (2017 a) Ressources alimentaires de Eidolon helvum (Kerr, 1792), espèce proche de la menace (Abidjan, Côte d' Ivoire). European Scientific Journal 13:182-196.

Niamien CJM, Kadjo B, Dago DN, Koné I, N'Goran KE (2017 b) Spatiotemporal distribution of Eidolon helvum (Kerr, 1792) Nearthreatened Species (Côte D'Ivoire, West Africa). International Journal of Scientific Engineering and Applied Science 6: 70-77.

Nordt A, Klenke R (2013) Sleepless in town-drivers of the temporal shift in dawn song in urban European blackbirds. Plos One 8:1-10.

O'Shea TJ, Bogan MA, Ellison LE (2003) Monitoring trends in bat populations of the United States and territories: Status of the 
science and recommendations for the future. Wildlife Society Bulletin 31:16-29.

Ramade F (2012) Éléments d'écologie : Ecologie appliquée, $7^{\text {ème }}$ édition. Dunod, Paris.

Richter HV (2004) The foraging ecology of fruit bats in the seasonal environment of central Zambia. Master of Sciences of University of Florida, Florida.

Richter HV, Cumming GS (2006) Food availability and annual migration of the straw-colored fruit bat (Eidolon helvum). Journal of Zoology 268:35-44.

Saéz AM, Weiss S, Nowak K, Lapeyre V, Zimmermann F, Düx A, Kühl HS, Kaba M, Regnaut S, Merkel K, Sachse A, Thiesen U, Villányi L, Boesch C, Dabrowski PW, Radonić A, Nitsche A, Leendertz SAJ, Petterson S, Becker S, Krähling V, CouacyHymann E, Akoua-Koffi C, Weber N, Schaade L, Fahr J, Borchert M, Gogarten JF, Calvignac-Spencer S, Leendertz FH (2015) Investigating the zoonotic origin of the West African Ebola epidemic. Embo Molecular Medicine 7:17-23.

Taylor DAR, Kankan BO, Wagner MR (2000). The role of the bat fruit, Eidolon helvum in seed dispersal, survival, and germination in Milicia excela, a threatened West African hardwood. Biotropica 18:1-4.

Thomas DW (1982) The Ecology of an African savanna fruit bat community: Resource partitioning and role in seed dispersal. Thesis of University of Aberdeen, Aberdeen.

Thomas DW (1983). The annual migration of three species of West African fruit bats (Chiroptera: Pteropodidae). Cannadian Journal of Zoology 61: 2266-2272.

Thomas DW (1984) Fruit intake and energy budgets of frugivorous bats. Journal of Physiology Zoology 57: 457-467.

Thomas DW (1988) Analysis of diets of plant-visiting bats. In Kunz TH (Ed). Ecological and behavioral methods for the study of bats, Smithsonian Institution Press, Washington, USA.

Williams-Guillén K, Olimpi E, Maas B, Taylor PJ, Arlettaz R (2016) Bats in the Anthropogenic Matrix: Challenges and Opportunities for the Conservation of Chiroptera and Their Ecosystem Services in Agricultural Landscapes. In: Voigt CC, Kingston $\mathrm{T}$ (Eds.), Bats in the Anthropocene: Conservation of bats in a changing world, Springer International, Berlin, Germany. 